\title{
HOME OFFICE SPACES FOR SMART WORK. IMPACT OF COVID-19 LOCKDOWN ON ARRANGEMENTS OF RESIDENTIAL INTERIORS
}

\author{
DOMOWE PRZESTRZENIE PRACY ZDALNEJ. WPŁYW DYSTANSU \\ SPOŁECZNEGO W TRAKCIE COVID-19 NA ARANŻACJE \\ WNĘTRZ MIESZKALNYCH
}

\section{Agata Bonenberg}

Prof. dr hab. inż. arch.

Author's Orcid number: 0000-0003-1618-4417

Politechnika Poznańska, Poland

Wydział Architektury

Dyrektor Instytutu Architektury Wnętrz i Wzornictwa Przemysłowego

\section{Marco Lucchini}

Prof.

Author's Orcid number: 0000-0001-8051-3313

Politecnico di Milano, Italy

Dipartimento di Architettura e Studi Urbani

\begin{abstract}
The Covid-19 pandemic has encouraged a shift to smart-working both for companies as well as their employees. Work-related activities once performed in dedicated offices had to be moved to private spaces of individual homes, severely influencing how people use their residential space. Living and working conditions have been modified and the balance between them - interrupted. In this paper the authors present a study of the changes in the use of residential space based on questionnaires addressed to respondents in five age groups (up to 25, 26-35, 36-50, 51-65, more than 65), and living or studying in and around Milan (Lombardy), an area affected severely by Covid-19 between March and May 2020. The obtained questionnaire results have allowed the authors to create a set of apartment design requirements, which improve the performance of space. Research has led to a model-case study apartment.
\end{abstract}

Key words: residential architecture and interior design, social isolation, lockdown, Covid19 pandemic, working and studying routines, creativity. 


\section{STRESZCZENIE}

Pandemia Covid-19 zmusiła do przejścia w tryb pracy zdalnej rzesze pracowników. Czynności dotychczas wykonywane w przeznaczonych do tego biurach, zostały przeniesione do prywatnych przestrzeni indywidualnych domów, co wpłynęło na sposób, w jaki ludzie wykorzystują przestrzeń mieszkalną. Warunki życia i pracy uległy zmianie, a dotychczasowa równowaga między nimi zaburzeniu. W niniejszej pracy autorzy przedstawiają badania zmian zachodzących w użytkowaniu przestrzeni mieszkalnej na podstawie ankiet skierowanych do respondentów w pięciu grupach wiekowych (do 25 lat, 26-35 lat, 36-50 lat, 51-65 lat, powyżej 65 lat), mieszkających lub uczących się w Mediolanie (Lombardia) i jego okolicach, na obszarach silnie dotkniętych przez Covid-19 w okresie od marca do maja 2020 roku. Uzyskane wyniki pozwoliły autorom na opracowanie zestawu wymogów dotyczących projektowania mieszkań, uwzględniając domową przestrzeń biurową. Badania doprowadziły do realizacji modelowego mieszkania.

Słowa kluczowe: architektura mieszkaniowa i projektowanie wnętrz, izolacja społeczna, lockdown, pandemia Covid19, rutyna pracy i nauki, kreatywność.

\section{INTRODUCTION}

The Covid-19 pandemic has encouraged a shift to smart-working both companies as well as their employees. Since the Covid-19 outbreak, many predictions, statements, and ideas have been expressed on how the pandemic will affect the living environment, and how this environment should change to limit the risk of contagion. Work-related activities once preformed in dedicated offices had to be moved to private spaces of individual homes, severely influencing how people use their residential space. Living and working conditions have been modified and the balance between them - interrupted. The purpose of the study presented in this paper was to research the changes in the use of residential space using questionnaires addressed to respondents in five age groups (up to $25,26-35,36-50,51-65$, more than 65 ), and living or studying in and around Milan (Lombardy), an area affected severely by Covid-19 between March and May 2020. The obtained questionnaire results and analysis of research by design case studies have allowed authors to create a set of apartment design requirements, later applied to a case study apartment in Genova. The authors investigated how respondents coped with the necessity of living and working in restricted areas of their homes, how they perceived the experience, and how they changed their living environments. The obtained results are significant because they can be applied not only in a pandemic context, but in any situation when social separation or privacy is necessary. In conclusion, the authors confirm the relevance, adequacy, and benefit of applying guidelines, derived from an analysis of questionnaire result, to a model apartment.

The current state of the research shows diverse ideas, predictions, and concepts regarding the effects of social distancing on interior design, architecture, and urban planning. An extensive overview presented in Antivirus-built environment: Lessons learned from Covid-19 pandemic by Naglaa A. Megaheda, Ehab M. Ghoneim (Naglaa A. Megaheda, Ehab M., 2020) supports the prediction of highly profound spatial changes, which pandemics cause in urbanism, public spaces, housing, office spaces, building and construction technology. Suggestions of more divided residential interiors, combined with flexible spaces, are already observed in the real estate market. An overview regarding aspects of sustainability in connection with COVID-19 has been described in The problem of change in sustainability requirements by Galym Tokazhanov (Howis). In most articles, the 
dominating idea is that the built environment has a significant role to play before (prevention), during (containment and mitigation via segregation), and after (contingency planning and countermeasures for offsetting future risks) epidemics. Emerging evidence points to links between urban attribute-related individual activities and risks of infections. (Ka Yan Lai, Webster C., Kumari S., Sarkar C, 2020)

In How Architecture Fails in Conditions of Crisis: a Discussion on the Value of Interior Design over the COVID-19 Outbreak (Rassia S., 2020) offers a dramatic vision of architectural failure in the face of the threat posed by Covid-19. The authors of this manuscript do not share such extreme beliefs. Willingness to remain a community will continue to fuel the attractiveness of city life, with high-density architecture and multi-apartment residential buildings. It does not mean, however, that nothing has changed. The change came in the form of strengthening an already existing trend: smart-working. Partial adaptation to the new way of working seems to be the solution to many contemporary issues: traffic, pollution, and stress. And now there is another argument for working from home, whenever possible: Covid-19. With this opportunity comes, however, one major problem in creating high-quality environments for vast populations of people. Until now, creating optimal working space was a domain of architects and interior designers employed to professionally produce ergonomic working conditions in office buildings. Now this task is in the hands of the general public. People are having to adapt private apartments where workspaces have often not even been foreseen. Non-ergonomic, unprofessional solutions can create serious health risks and, as a result, decrease work efficiency. For this reason, the authors of this manuscript consider working space at home the essential aspect of the change. The working hypothesis consists of the following:

- private apartments are insufficiently equipped to serve smart working

- there is a relation between the working conditions at home and acceptance of the concept of smart working

- there are many spatial arrangements and behavioural strategies to improve the comfort of work and work-life balance

A vital element of this study is a set of guidelines for work or study areas located in apartments which should be widely communicated.

\section{METHOD}

The methods used in this research are multidisciplinary and combine theoretical and practical design approaches. The study is based on the following methods and divided into four stages:

An analysis of bibliographical materials.

A questionnaire taken by 226 people concerning the first lockdown in Italy: March-May 2020. Respondents were divided into five age groups: up to $25,26-35,36-50,51-65$, more than 65 , live permanently or temporarily in and around Milan (Lombardy). Each participant was tested individually, with no interaction with others. All survey participants were informed in advance that they would be participating in a study investigating the effects of pandemic isolation on living space use.

An analysis of questionnaire results and bibliographical research, to create a set of guidelines for home office design.

Execution of a model apartment in Genova, Italy in August 2021 (research application).

The questionnaire was divided into five specific topics corresponding with typical actions undertaken at home: working and studying (1), physical activity and sports (2), cooking and eating (3), leisure and entertainment (4). The questionnaire began with a general section featuring questions regarding the size of the apartment in which the person stayed, residence typology, and its internal arrangement.

The Working And Studying section examined the necessity of starting or increasing the volume of work done from home. It included questions on the amount of time spent working from home, intentions regarding the continuation of working or studying partially or even entirely from home after the emergency end. Inquiries were made regarding the physical space in which work or study takes 
place, like a separate studio, living room, bedroom, kitchen or garden. The sufficiency of the space and applied means of improvement were investigated. There was also a descriptive question regarding the perfect. The Physical Activity And Sports section focused on the impact of lockdown on fitness. It included questions regarding the amount of time spent on physical activities and sports at home, on spaces in which they were performed (private gym, living room, bedroom, garden, balcony, on the sufficiency of space for physical activity and possible improvements to the workout space. Inquiries were made as to one's willingness to continue sports routines at home after the emergency comes to an end. The Cooking And Eating section concentrated on culinary habits and the consumption culture. During the pandemic, the possibilities of eating out became a subject of limitations; on the other hand, families tended to spend more time together, eating and often cooking collectively. Therefore, changes and adjustments in the kitchens and dining areas to new routines were analysed. Finally, the section Leisure And Entertainment featured preferred types of entertainment during the COVID-19 lockdown and the kinds of space respondents used for the purpose. In this paper, the authors concentrate on presenting the results of the Working And Studying From Home section as the most critical area.

\section{RESULTS}

Research results have been obtained in four areas:

- Bibliographical research results (3.1.):

- The city as a place of work during social distancing (3.1.1.)

- High-density residential buildings and anti-contagion strategies (3.1.2.)

- The office: home-based, virtual, flexible, work arrangement (3.1.3.)

- Questionnaire results (3.2.)

- Observation of a model-case study: apartment in Genoa, Italy in August 2021 (3.3.).

\subsection{Bibliographical Research Results}

According to Google Scholar, the number of peer-reviewed articles concerning interior design, architecture, and urban design has gone up to 422000 results, making it a mainstream topic in the field. For the authors, it was crucial to include sources of information like recent documents, news and expert opinions expressed online on thematic websites in the ongoing discussion. The image appearing from bibliographical research is overly complex.

\subsubsection{The city as a Place of Work During Social Distancing}

Cities and towns have always been physical manifestations of a complex organization aiming to advance the production of goods and provision of services. As a constant target of migration for a better economic future, cities have become areas based on work and growing through work. The types of residential architecture used in the urban tissue, strongly mirrors the work-related activities of the residents. The fundamental historical occupation - urban tissue relationship has been altered and modified by other factors, of which hygiene is probably the most important. The balance between work and health within city boundaries has been of key importance. In the 14th century, the bubonic plague encouraged critical urban transitions of the Renaissance. An attempt was made to rearrange and limit substandard, overpopulated city quarters, develop quarantine facilities, introduce vast communication streets and even larger open squares. Ideal Renaissance cities were being designed according to these principles. Furthermore, in the 19th and 20th centuries, infectious diseases were one of the reasons for the introduction of urban parks and green areas for children. With the onset of the industrial era, diseases influenced sanitary reforms, contributing to the development of water and sewage systems. This basic infrastructure required streets to be straighter and wider, and it contributed to the contemporary city image as we know it today (Budds, D, 2020). Modernists perceived architectural design and urban planning as means to cure the sickness of overcrowded districts, liberating them from outbreaks of tuberculosis, typhoid and polio (Chang, V., 2020, Lubell, S., 2020). 
Concerning the composition of the city, the ordinary activities of inhabitants should be analysed. "There is a connection between activities of an individual related to urban life and risks of infections: pathogens are spread by mobile vectors, a city's plan and architecture shape their flows." (Lai K.Y., Webster C., Kumari S., Sarkar C, 2020) Referring to the relationship between public health and living conditions, research shows that high density leads to the spread of volatile infections and droplet-transmitted infections (Capolongo, S., et al., 2020). Following the outbreak of Covid19, predictions have been made about a crisis of cities caused by high densities, depicting an image of abandoned centres and the decline of vibrant city life as we know it. The authors do not share such radical views but choose to join calls for necessary improvements. Planning should be taken into consideration when discussing the subject of high-quality spaces for working from home. In the research presented above, respondents underlined the importance of direct sunlight in a flat, possibility of contact with greenery for most efficient work, and high-standard living conditions. This situation can only be assured when there are adequate distances between buildings to allow sunlight to penetrate the urban tissue. Good urban planning decisions are required to enable close contact with greenery. It is essential to underline that a good standard in the neighbourhood is a pre-requisite for high quality home offices in multistorey residential buildings.

\subsubsection{High-Density Residential Buildings and Anti-Contagion Strategies}

In a contemporary city, most residential buildings are multistorey. There are several ways multifamily condominiums can be constructed or altered to be safe in the Covid-19 pandemic. Employing good maintenance routines, ICT technologies, and touch-less solutions from the entrance to the apartment door improves hygiene and safety (Priday, C., 2020). Technology can support social distancing, provide users with contactless access, which can be based on mobile solutions, voiceenabled solutions, or gesture detection technologies. It is possible to identify and authenticate individuals for quarantine purposes using sensors for measuring biometrics such as voice, iris images, facial features, behavioural characteristics (Hossam N., Zaher E., 2020). Interiors of public areas within multistorey residential buildings can be decorated and finished using materials limiting the growth or spread. With the advancement of modern technologies, antimicrobial surfaces with silver particles can be integrated within furniture, fabrics, and rugs to achieve hygienic or self-cleaning properties. Ultraviolet light technology can ensure measurably safer and cleaner environments and could be used in lifts or along staircases.

From an architectural standpoint, anti-contagion solutions could also include wider corridors and doorways. It is also essential to provide adequate ventilation in both the shared areas and private dwellings. In multistorey buildings, water and air filtration systems should be installed as a standard. Comfort levels should be improved, ensuring natural sunlight has access to living areas and residents have access to greenery - conditions purely depending on city planning. Indoor gardens should be encouraged (Makhno, S.,2020; Wainwright, O., 2020).

A discussion regarding apartment size and plan in terms of safety is necessary also because of the increasingly more widespread phenomenon of flat sharing, particularly in global metropolitan areas. Apartment sizes and layouts should support physical distancing according to national health guidelines for shared dwellings. Physical distancing between residents to ensure comfort and safety within shared dwellings has to be borne in mind. YouGov, a British online survey, found that $31 \%$ of adults have experienced mental or physical health issues due to the quality of living conditions within their homes during lockdown (Sansom, 2020). Furthermore, the survey indicated that 30,000 Britons had spent city lockdowns in one-room dwellings (Peters T., Halleran A., 2020). In this context, avoiding tiny, substandard dwellings, employing flexible housing solutions that can support self-isolation within shared units could become critical in containing the spread.

\subsection{Questionnaire Results}

Data obtained from the questionnaires were quantified, cross-referenced, and analysed. $78 \%$ of the respondents declared that they had to switch to online working or studying. Most people claiming that they did not switch to online activities were in the over 65 years old age group. Even though social isolation caused negative feelings of anxiety or annoyance, it seems that the experience was 
not entirely negative, as less than half $(43 \%)$ of the respondents would prefer reverting to exclusively in presence working or studying. This result indicates that the Covid-19 pandemic has stimulated a trend that is probably here to stay. $57 \%$ of the group would like to continue working and studying in a hybrid way. Furthermore, $17 \%$ declared that they would like to remain entirely online. It could mean that moving activities online is not merely a response to a short-lasting emergency.

There is evidence that openness to smart working is related to the conditions in which one works. Respondents who perceive their current home working space as sufficient with respect to their needs are more open to online working now and in the future. In the group who provided a positive answer to "Is your working space sufficient?", 68 \% would like to continue working or studying partially from home after the emergency ends. In the group in which working conditions are insufficient, that figure is only $54 \%$ (Fig. 1 ).

\section{WOULD YOU LIKE TO CONTINUE WORKING OR STUDYING PARTIALLY FROM HOME AFTER THE EMERGENCY FINISHES?}

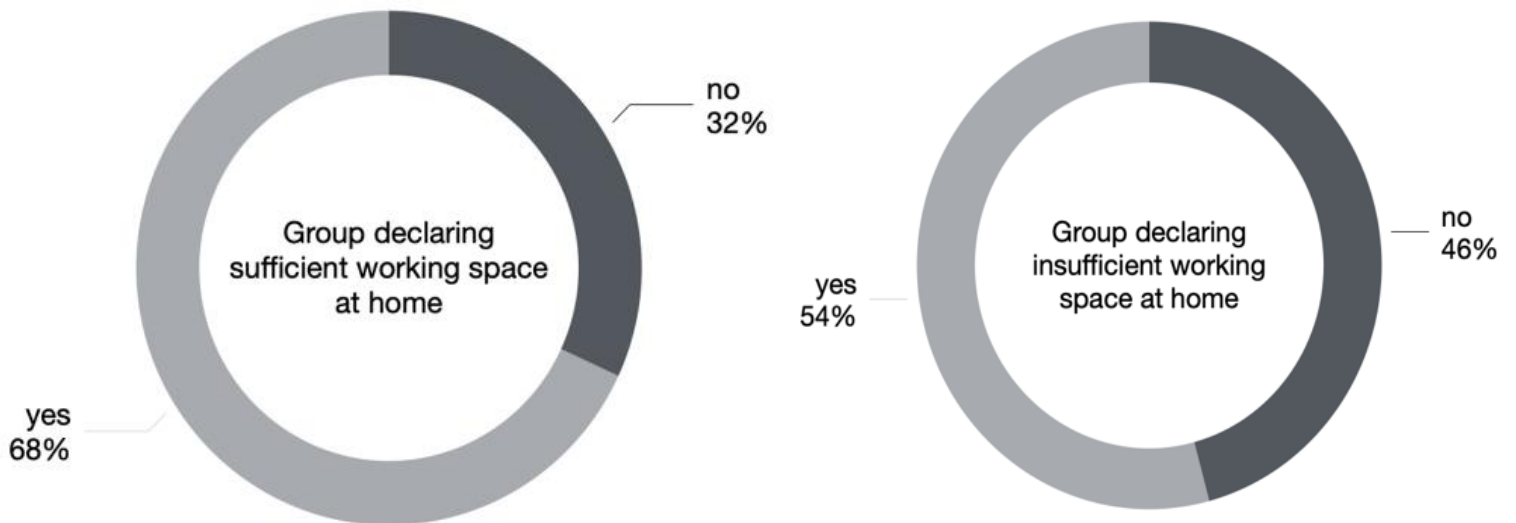

Fig. 1. Comparison between groups with sufficient and insufficient home office space regarding the willingness to continue working or studying partially from home after the emergency finishes. Source: author

Ryc.1. Porównanie pomiędzy grupami respondentów z wystarczającą i niewystarczającą przestrzenią do pracy domowej w kontekście chęci kontynuowania pracy zdalnej po zakończeniu pandemii. Źródło: autorzy

Spatial changes in apartment design are worth considering, as they shape people's work modality decisions. Living conditions, which are adequate when working purely outside the home, become substandard when work starts to be carried out in the place of residence. This situation raises questions regarding the introduction of building guidelines advocating the inclusion of workspace. The tendency for choosing larger flats or family homes is already visible in the data from immobility markets since the start of the pandemic. Additional space became more appreciated. It will probably take time to popularize the idea that a well-designed studio, home-office, or at least enclosed working space is essential from now on. Curiously, individual assessment of self-organized working space tends to be high. When asked about the sufficiency of working spaces, $74 \%$ declared that space is sufficient, even though only $13 \%$ have a separate room for work (Fig.2.) 

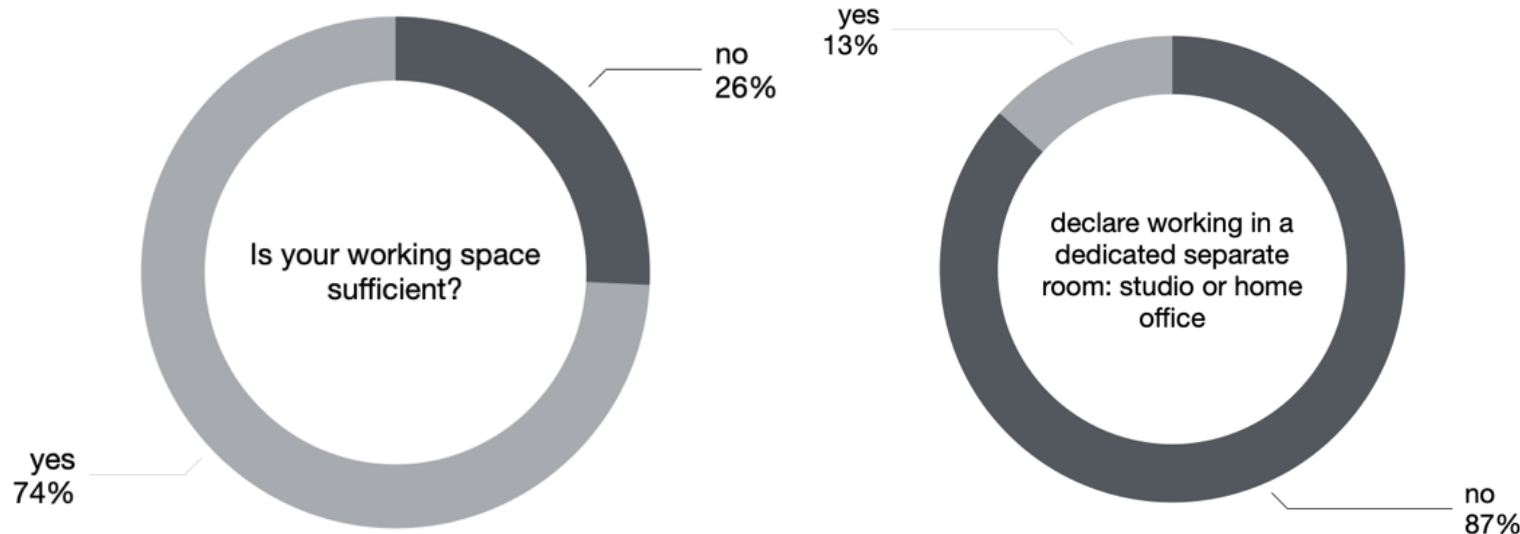

Fig. 2. Comparison between the number of people declaring sufficient working space and ones who work in a dedicated studio or home office. Source: author

Ryc. 2. Porównanie pomiędzy ilością osób deklarujących wystarczającą przestrzeń pracy i tych którzy deklarują pracę w oddzielnym pokoju: studio lub „home office”. Żródło: autorzy

This observation shows that the general public has not yet recognized the need for a high-standard workspace. Homemade "working corners," apart from being far from comfortable, can bring health risks to the user. On the other hand, work performed from the bedroom or living room can be productive and does not have to present health risks, only under the condition that work organization, furnishings and lighting systems follow the principles of ergonomics- as professionally arranged office spaces in office buildings do.

When asked about where they work at home, respondents most frequently pointed to bedrooms $(44 \%)$, living areas $(33 \%)$, kitchens $(5 \%)$, and external spaces like a garden, balcony, or a garage $(5 \%)$. These results indicate that introducing and popularising a set of guidelines for setting up high-quality working spaces would be essential (Fig.3.)

Some of the respondents added photographs illustrating home-arranged workspaces to their questionnaires. Examples of attached photos are shown below and can be treated as an extra insight into the randomly arranged situations. Apart from examples A, B which are separated studios, $C$ (bedroom) and D (garden) represent random conversion and adaptation to a work purpose.

Figure 3. Distribution of spaces in which respondents work from home. Source: author

Ryc.3. Zestawienie procentowe najbardziej popularnych przestrzeni w których respondenci pracują zdalnie. „Gdzie Pani/Pan pracuje podczas pracy zdalnej?”. Żródło: autorzy
Where do you usually work when at home?

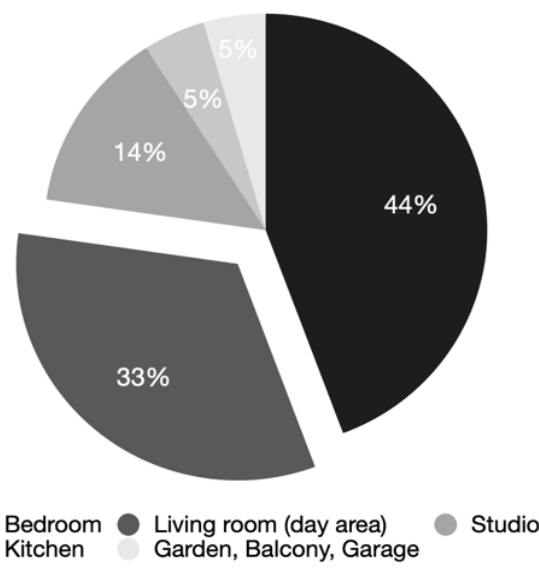


The problem of ergonomics in home-arranged workplaces is significant because of the exceedingly long time that respondents claim to spend in it. $44 \%$ claim that they work at home more than 8 hours a day, and further $26 \% 5-8$ hours (Fig.4.). As a result, a healthy working environment becomes of crucial importance. The correct chair height, adequate equipment spacing, light, and good desk posture - can help keep a healthy routine. Professionally designed and equipped offices must meet these standards. And that does not necessarily hold true for home-prepared offices.

Respondents asked about the changes they would introduce to a home workspace claimed that they would enlarge or rearrange the work or study space at home. They indicated better access to natural light, separation from noise, and more privacy as essential comfort factors (Fig.5.). It is worth underlining that issues like more sun or greenery in front of the windows are related to urban planning decisions; for this reason, the authors have taken it under consideration in bibliographical research.

How much time did you spend working

from home during COVID19 emergency?

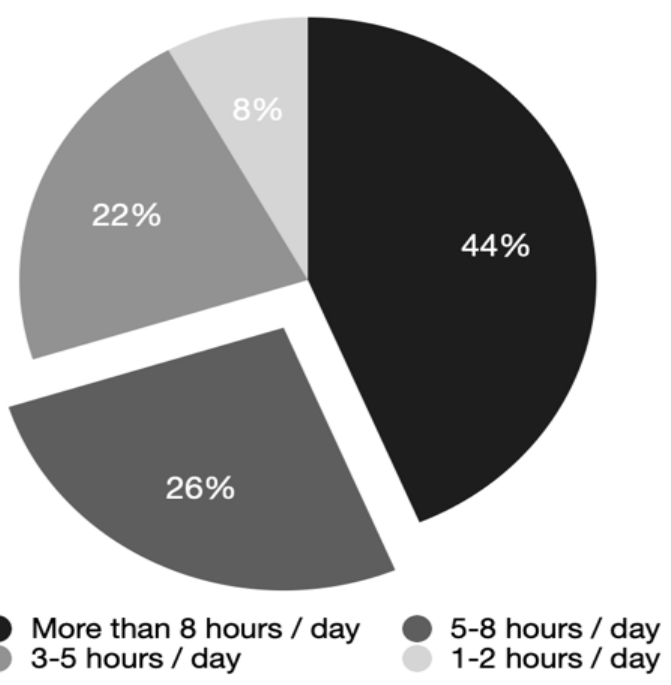

Figure 4. Distribution of average work times. Source: author

Ryc. 4. Czas wykonywania pracy zdalnej. "lle czasu dziennie spędziła Pani/Pan pracując $z$ domu podczas COVID19?" Zródło: autorzy

What would you improve in your working space at home?

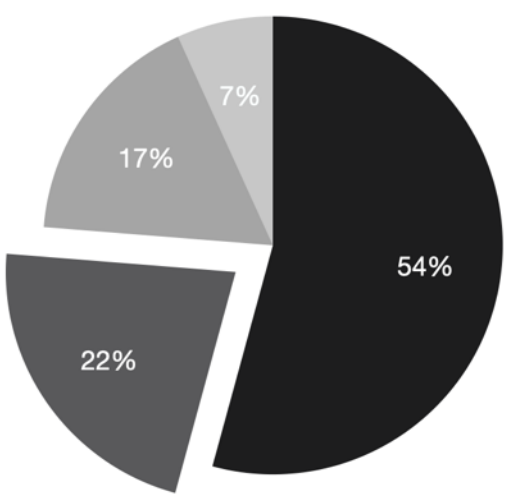

More space, space arranged in more efficient manner (furniture, storage, flexible sollutions) Better access to natural light

Separation from noise, privacy

Contact with greenery and fresh air

Figure 5. Workspace improvements which respondents would like to introduce in their homes. Source: author

Ryc. 5. Poprawa przestrzeni pracy; elementy które respondenci chcieliby poprawić we własnych domach. „Co chciałaby Pani/Pan poprawić we własnej przestrzeni pracy domowej?”. Żródło: autorzy 


\section{SET OF GUIDELINES FOR WORK OR STUDY AREAS LOCATED IN APARTMENTS}

Based on questionnaire analysis and bibliographical research results, when arranging or refurbishing working or studying areas, the following guidelines should be taken into consideration:

- When possible, develop working/studying areas as separate rooms that provide the best isolation and privacy for users. Include acoustic wall insulation when adapting rooms for working/studying areas. If impossible, use locations that offer privacy during working hours. Working or studying areas can be arranged in bedrooms, living rooms, and many other spaces under the condition of correct organization.

- Prioritize spaces with natural light, locate working areas close to windows, and provide adequate intensive artificial illumination of working areas. Additional sources of light are necessary for videoconferencing or registering video materials. For this, an effective blackout system (curtains, shutters) is necessary.

- Within a home office, arrange task areas with an adequate hierarchy: main working space with a computer station, creative worktops for drawing and writing if needed, reading and relaxing area preferably combined with a library, external working space for example on a terrace to avoid monotony.

- Use flexible furniture equipped with an abundance of space for storage, with adequate separators. All furniture and computer positions have to meet ergonomic standards and use materials and finishes which are easy to clean and sanitize. In addition, an office needs proper technical equipment.

- Take under consideration the possible setups and backgrounds for videoconferencing. It is often possible to have more than one videoconferencing arrangement.

- To reduce stress and maintain an excellent work-life balance, introduce spaces for other activities within the apartment. These could include workouts areas, relaxation areas, entertainment, and others.

\section{MODEL-CASE STUDY APARTMENT IN GENOA, ITALY}

In August 2021, an apartment design that followed the guidelines derived from the research described above was completed in Genoa, Italy. It acts as a research by design case study, used to observe and assess the implemented solutions. An ex-children's room has been converted into an office space meant for two users. The room's interior has been divided into a principal working area with two office desks, a reading corner with soft furniture and a library, and an additional temporary workspace on the balcony. Movable flexible worktops have been introduced to enable creative work with video filming or video transmission options. The office has been designed to perform well in the following work modalities:

- Video conferencing

- Video conferencing with life - drawing and painting studio

- Quiet work or study (with use of home-library resources)

- Creative work (drawing, painting) and filming the process

- Reading and relaxation

\subsection{Ergonomics}

For optimal video conferencing, additional artificial illumination was added, and webcam supports were implemented to position the webcam correctly. An effective blackout system of shutters has been put in place. Acoustic insulation panels have been used on the room walls to isolate it from the rest of the apartment. For quiet work or study, desks have been located close to the windows. Fully adjustable was used to meet ergonomic requirements: the height of desks and office chairs are easy to regulate so that feet rest flat on the floor or on a footrest, and thighs are parallel to the floor. Chairs support spinal curves. Adjustment of armrests is possible to support arms and relax shoulders. The room has been equipped with a footrest if non-movable worktops are in use. Flexible storage furniture has been introduced to accommodate work materials. For creative work 
(drawing, painting) and filming, additional movable worktops have been included with additional lighting. All frequently used objects (telephone, stapler, or printed materials) have been located close to minimize reaching. A monitor has been placed directly in front of the seating, the top of the screen slightly below eye level. To the left, one window overlooks the greenery outside to enable the stress from monitor exposure to be released. The monitor is located directly behind a keyboard, and a computer mouse remains within easy reach on the same surface.

For relaxed studying and reading - a dedicated area has been equipped with soft furniture and a library. This area enables one to change body positions during work when professional activities are related to information intake like reading printed materials but do not require using a computer.

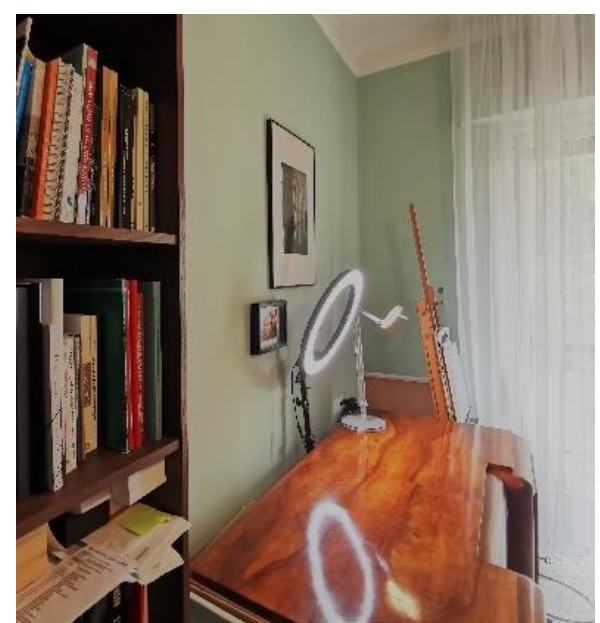

Fig. 6. Case study flat; home office area. Photographic survey of executed apartment design Source: author

Fig. 6. Studium przypadku; przestrzeń pracy domowej. Inwentaryzacja fotograficzna zrealizowanego projektu. Źródło: autorzy

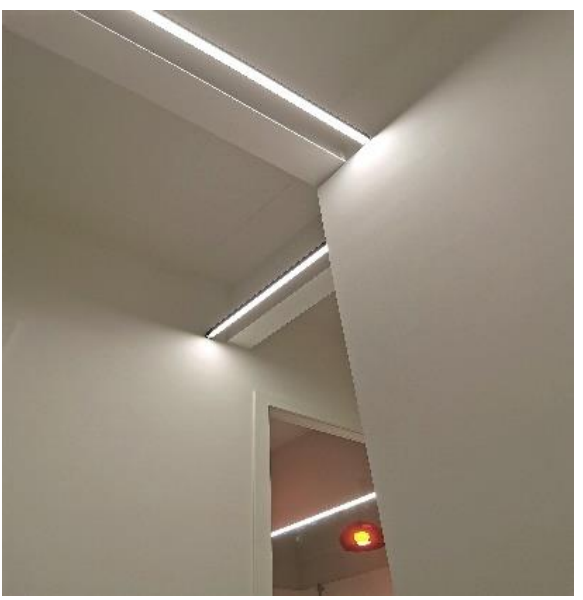

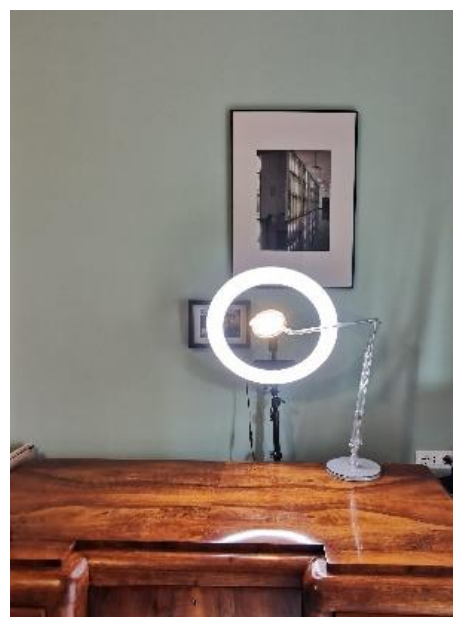

Fig. 7. Case study flat; home office area. Photographic survey of executed apartment design Source: author

Fig. 7. Studium przypadku; przestrzeń pracy domowej. Inwentaryzacja fotograficzna zrealizowanego projektu. Żródło: autorzy

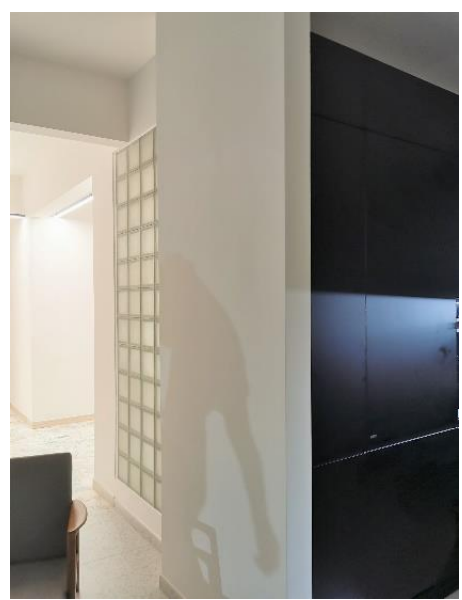

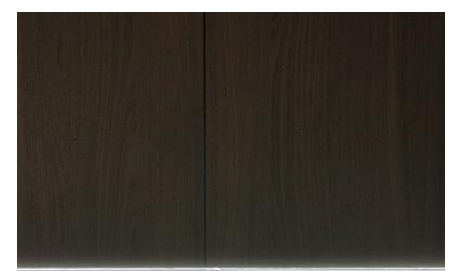

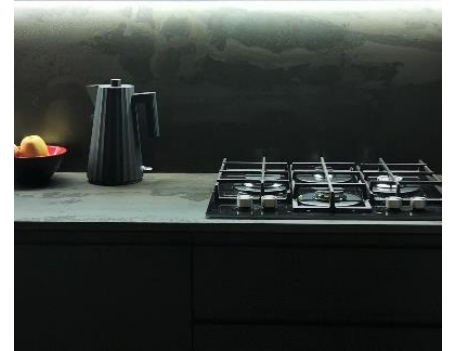

Fig. 8. Case study flat; kitchen detail. Photographic survey of executed apartment design Source: author

Fig. 8. Studium przypadku; detaj kuchni. Inwentaryzacja fotograficzna zrealizowanego projektu. Źródło: autorzy

Fig. 8, 9, 10 Case study flat; circulation. Photographic survey of executed apartment design. Source: author

Fig. 8. Studium przypadku; przestrzeń cyrkulacji. Inwentaryzacja fotograficzna zrealizowanego projektu. Źródło: autorzy 


\subsection{Stylistics Inspired With Greenery and Plant Patterns}

The "furnishing with plants" concept has been introduced as the primary attribute of aesthetics in the studio. Greenery has become the main ornament in the room, and all other interior design elements repeat its patterns, colours, and moods. The studio has been painted in salvia green, visually expanding towards the balcony, and the intense, natural greenery outside. An additional small working space has been foreseen on the balcony as well. Plant leaf motifs are present on soft furniture of the reading space as it introduces the spirit of calmness and underlines connection with nature. The furniture exhibits contemporary stylistics; the walls have been decorated with black and white photographs to introduce a semi-formal look of the work environment suitable as a background for videoconferencing. Creating a formal looking space is an essential element of the new work culture related to revealing views of private spaces through videoconferencing.

\subsection{Stress-Release}

An alternative working space has been arranged on the eastern balcony. It is possible to close it off with a shutter. The studio also features direct access to a fitness area, which has been arranged in a demolished storage room previously located in a central position of the flat. The sports area includes one fixed element: An exercise bike and several removable exercise mattresses, yoga mats, a relaxing massage mat as well as exercise weights.

\section{DISCUSSION}

The popularization of work from home became a fact and an urging challenge for architects and interior designers. The concerns expressed in the working hypothesis assumed by the authors have been confirmed. A considerable part of the respondents declared their private apartments insufficient to serve studying or smart working. At the same time, a clear relation between the working conditions at home and acceptance of the concept of smart working has been proven: the poorer the conditions of work in a private residence, the less accepting the approach to WFH. It is important to underline that individual behaviour regarding time at work, and other activities such as workouts or relaxation are decisive in improving the work-life balance during and after a forced social isolation.

Summing up, the research results derived from the questionnaire and research by design study are in line with conclusions encountered within publications. At this point of the pandemic, the authors do not agree with definitive and negative statements regarding the future of cities and ideas that the only adequate answer for pandemics is a single-family, detached house. This approach would be harmful and potentially disastrous for urban planning. The authors established the means and measures to help make home offices located in multiple flat condominiums comfortable, efficient, and stimulating. Apartment plans offer spaces for various functions: sports, workout, relaxation; joint activities are aimed at providing diverse activities and keeping a good work-life balance. In this context, it is worth considering that in historical living-working patterns, performing professional activities from one's home was the norm. Traditional workshops of artisans, merchants and shopowners were usually located on the ground floor of tenement houses, with the owners residing on upper floors. Private and business lives were interconnected, and even more importantly imbedded in a vaster, social tissue of a town or city quarter. Nowadays, it has become a social norm to strictly separate the private from the professional. And as the job, performed in a distant anonymous office, became the predominant force, other aspects lost their importance. Smart working has made the home more inhabited. Could this also affect social life beyond the four walls of private apartments? Maybe it could rebuild the traditional social involvement at neighborhood level and help celebrate the given location.

The other opinion, oft seen in bibliographical research, heralds the end of the trend for open spaces in residential architecture, caused by the need for family members or flat mates to divide rooms for quiet work and study. These arguments could hold true for small residential units. Indeed, in a small apartment, the priority would be to provide privacy and separation for all family members. However, the solutions presented in the research by design (3.3.) section show that it is possible to 
install well-organized, separated, pop-up office units within existing bedrooms, living rooms, and others. In many cases, it would allow for keeping the perception of a vast, unobstructed space. In large apartments, where there are spare rooms which can be enclosed, a central open area could still be an attractive place of get-togethers, family activities, leisure, entertainment, used for workout activities, and others. It could the end of claustrophobic, oppressive, closed environments.

Future research into this thematic area, which the authors have already undertaken, feature analyses of activities and routines performed at home during lockdown periods: entertaining, working out as well as cooking, and eating habits. In addition, it will become essential to understand timebased engagement and the influences between the various activities and spaces.

\section{CONCLUSIONS}

The end of the COVID-19 pandemic still seems far away. However, acceptance of smart working will most probably grow, and the digital cultural revolution will continue even after the emergency ends. After completing this research, it became clear that expert knowledge on arranging workspaces at home should be widely communicated. Ergonomics in creating healthy, comfortable offices is very strictly followed in designing professional office arrangements. The time has come to set a similar standard for home offices. The general public should not be left to its own devices in trying to cope with this task. Non-professional, inadequate arrangements will result in health risks and a decrease in the acceptance of smart work, as less efficient and less comfortable. Companies allowing employees to work from home should provide them with help, know-how, or even predesigned furniture units to support their staff in dealing with these challenging tasks.

\section{DOMOWE PRZESTRZENIE PRACY ZDALNEJ. WPŁYW DYSTANSU SPOŁECZNEGO W TRAKCIE COVID-19 NA ARANŻACJE WNĘTRZ MIESZKALNYCH}

\section{WPROWADZENIE}

Pandemia Covid-19 zmusiła pracowników do przejścia w tryb zdalny. Wraz z wybuchem pandemii Covid-19 pojawiło się wiele koncepcji i spekulacji dotyczących tego, jak wpłynie ona na środowisko życia i jak to środowisko powinno się zmienić, aby ograniczyć ryzyko zarażenia. Czynności związane z pracą, które wcześniej były wykonywane w budynkach biurowych, musiały zostać przeniesione do prywatnych przestrzeni domowych. Wpłynęło to poważnie na sposób, w jaki ludzie wykorzystują swoją przestrzeń mieszkalną. Warunki życia i pracy uległy modyfikacji, a równowaga między nimi - zaburzeniu. Celem badań przedstawionych w niniejszej pracy było zbadanie zmian w użytkowaniu przestrzeni mieszkalnej za pomocą ankiet skierowanych do respondentów w pięciu grupach wiekowych (do 25 lat, 26-35 lat, 36-50 lat, 51-65 lat, powyżej 65 lat), mieszkających lub uczących się w Mediolanie (Lombardia) i jego okolicach, w obszarze dotkniętym szczególnie przez Covid-19, w okresie od marca do maja 2020 roku. Uzyskane wyniki ankiety pozwoliły autorom na stworzenie zestawu wymogów dotyczących projektowania mieszkań, zastosowanych następnie przy realizacji modelowego mieszkania w Genui.

Autorzy zbadali, jak respondenci radzili sobie z koniecznością życia i pracy w ograniczonych przestrzeniach ich domów i mieszkań, jak postrzegali to doświadczenie i jak zmienili swoje środowisko życia. Uzyskane wyniki są istotne, ponieważ mogą być zastosowane nie tylko w kontekście pandemii, ale w każdej sytuacji, w której konieczna jest społeczna separacja lub zachowanie prywatności. 
Przegląd stanu badań ukazuje różnorodne pomysły, przewidywania i koncepcje dotyczące wpływu społecznego dystansu na projektowanie wnętrz, architekturę i urbanistykę. Publikacja „Lessons learned from Covid-19 pandemic" autorstwa Naglaa A. Megaheda, Ehab M. Ghoneim (Naglaa A. Megaheda, Ehab M., 2020) zawiera sugestie bardzo głębokich zmian przestrzennych, jakie pandemie powodują w urbanistyce, przestrzeniach publicznych, mieszkalnictwie, przestrzeniach biurowych, technologii budowlanej i konstrukcyjnej. Na rynku nieruchomości możemy już obserwować propozycje bardziej podzielonych wnętrz mieszkalnych, połączonych z elastycznymi przestrzeniami. W publikacji „The problem of change in sustainability requirements” autorstwa Galyma Tokazhanova" (Howis). opisane zostały różne aspekty zrównoważonego rozwoju w powiązaniu z COVID-19. W większości artykułów dominuje pogląd, że środowisko zabudowane ma do odegrania znaczącą rolę przed (zapobieganie), w trakcie (powstrzymywanie i łagodzenie poprzez segregację) i po (planowanie awaryjne i środki zaradcze w celu zrównoważenia przyszłych zagrożeń) epidemii. Przytoczone dowody wskazują na powiązania między działaniami związanymi z kształtowaniem miejskiej zabudowy a ryzykiem zakażeń. (Ka Yan Lai, Webster C., Kumari S., Sarkar C, 2020)

W książce "How Architecture Fails in Conditions of Crisis: a Discussion on the Value of Interior Design over the COVID-19 Outbreak" (Rassia S., 2020) przedstawiona została dramatyczna wizja architektonicznej porażki w obliczu zagrożenia spowodowanego przez Covid-19. Autorzy artykułu nie podzielają tak skrajnych przekonań. Pragnienie uczestnictwa we wspólnocie, dostępu do usług, kultury, ochrony zdrowia, nadal będzie wpływać na atrakcyjność życia w mieście, z jego architekturą o dużej gęstości i wielorodzinnymi budynkami mieszkalnymi. Nie oznacza to jednak, że nic się nie zmieniło. Zmiana polega na wzmocnieniu już istniejącego trendu: pracy zdalnej. Częściowa adaptacja do nowego sposobu pracy wydaje się być rozwiązaniem wielu współczesnych problemów: intensywności ruchu ulicznego, zanieczyszczenia, stresu. Wraz z tą możliwością pojawia się jednak poważny problem w tworzeniu wysokiej jakości indywidualnych środowisk pracy dla wielu użytkowników. Do tej pory tworzenie optymalnej przestrzeni pracy było domeną architektów i projektantów wnętrz, którzy profesjonalnie zajmowali się projektowaniem przestrzeni w wyspecjalizowanych biurowcach zgodnie $z$ wymogami ergonomii. Teraz zadanie to spada na indywidualnych pracowników. Ludzie muszą adaptować prywatne mieszkania, w których często nie przewidziano nawet dodatkowych przestrzeni na ten cel. Nieergonomiczne, nieprofesjonalne rozwiązania mogą powodować poważne zagrożenia dla zdrowia, a w konsekwencji obniżać efektywność pracy. $Z$ tego powodu autorzy niniejszego artykułu uważają przestrzeń roboczą $w$ domu za istotny aspekt zmian. Można postawić hipotezę że:

- mieszkania prywatne są obecnie niewystarczająco przygotowane, aby służyć pracy zdalnej

- istnieje związek między warunkami pracy w domu a akceptacją koncepcji pracy zdalnej

- istnieje wiele aranżacji przestrzennych i strategii behawioralnych poprawiających komfort pracy i przywracających równowagę między życiem zawodowym a prywatnym.

Istotnym elementem niniejszego opracowania jest zestaw wytycznych dla stref pracy lub nauki zlokalizowanych w mieszkaniach, które powinny być popularyzowane wśród pracowników.

\section{METODA}

Metody zastosowane $w$ tym badaniu mają charakter multidyscyplinarny i łączą teoretyczne i praktyczne podejście do projektowania. Badanie oparte jest na następujących metodach i podzielone na cztery etapy:

- Analiza materiałów bibliograficznych.

- Kwestionariusz wypełniony przez 226 osób dotyczący pierwszego lockdownu we Włoszech: marzec-maj 2020. Respondenci zostali podzieleni na pięć grup wiekowych: do 25 lat, 26-35 lat, 36-50 lat, 51-65 lat, więcej niż 65 lat, mieszkają na stałe lub tymczasowo w Mediolanie i okolicach (Lombardia). Każdy uczestnik był badany indywidualnie, bez interakcji z innymi. Wszyscy uczestnicy ankiety zostali wcześniej poinformowani, że będą brać udział w badaniu analizującym wpływ izolacji pandemicznej na wykorzystanie przestrzeni życiowej. 
- Analiza wyników ankiety i badań bibliograficznych, w celu stworzenia zestawu wytycznych do projektowania domowego biura.

- Wykonanie modelowego mieszkania w Genui, we Włoszech w sierpniu 2021 roku (aplikacja badawcza).

Kwestionariusz został podzielony na pięć tematów odpowiadających typowym czynnościom wykonywanym w domu: praca i nauka (1), aktywność fizyczna i sport (2), gotowanie i jedzenie (3), wypoczynek i rozrywka (4). Kwestionariusz rozpoczął się od części ogólnej, w której znalazły się pytania dotyczące wielkości mieszkania, w którym dana osoba przebywała, typologii miejsca zamieszkania oraz jego wewnętrznej aranżacji.

W części Praca i nauka badano konieczność podjęcia lub zwiększenia ilości pracy wykonywanej w domu. Zawierała pytania o ilość czasu spędzanego na pracy w domu, intencje dotyczące kontynuowania pracy lub nauki częściowo lub nawet całkowicie w domu po zakończeniu sytuacji kryzysowej. Pytano o fizyczną przestrzeń, w której odbywa się praca lub nauka, np. oddzielne studio, pokój dzienny, sypialnia, kuchnia lub ogród. Badano, czy przestrzeń ta jest wystarczająca i czy można ją ulepszyć. Stawiano również pytania opisowe dotyczące idealnych aranżacji poszczególnych typów przestrzeni. Sekcja Aktywność fizyczna i sport zawierała pytania dotyczące ilości czasu poświęcanego na ćwiczenia $\mathrm{w}$ domu, miejsc $\mathrm{w}$ których było one wykonywane (prywatna siłownia, pokój dzienny, sypialnia, ogród, balkon), adekwatności przestrzeni dla aktywności fizycznej oraz możliwych ulepszeń strefy treningowej. Pytano o gotowość do kontynuowania zajęć sportowych w domu po zakończeniu pandemii. Sekcja Gotowanie i Jedzenie koncentrowała się na zwyczajach kulinarnych i kulturze konsumpcji. W czasie pandemii została ograniczona możliwość jedzenia poza domem, z drugiej strony rodziny spędzały więcej czasu razem, jedząc i często gotując wspólnie. Dlatego też analizowano zmiany i dostosowania kuchni i jadalni do nowych zwyczajów. Wreszcie w rozdziale Wypoczynek i Rozrywka przedstawiono preferowane rodzaje rozrywki podczas COVID-19 oraz rodzaje przestrzeni, jakie respondenci wykorzystywali do tego celu. W niniejszym opracowaniu autorzy skupiają się na przedstawieniu wyników sekcji Working And Studying From Home jako najistotniejszego obszaru tematycznego.

\section{WYNIKI}

Wyniki badań zostały uzyskane w obszarach:

- Wyniki badań bibliograficznych:

- Miasto jako miejsce pracy w okresie dystansu społecznego

- Budynki wielorodzinne o dużej gęstości i strategie przeciw zakażeniom

- Biuro: praca w domu, wirtualna, elastyczna, organizacja pracy

- Wyniki badania ankietowego

- Obserwacja modelu-studium przypadku.

\subsection{Wyniki badań bibliograficznych}

Według Google Scholar, liczba recenzowanych artykułów dotyczących wpływu Covid-19 na projektowanie wnętrz, architekturę i projektowanie urbanistyczne wzrosła do 422000 , co sprawia, że jest to istotny nurt tematyczny $w$ tej dziedzinie. Obraz wyłaniający się z badań bibliograficznych jest złożony.

\subsubsection{Miasto jako miejsce pracy w czasach dystansu społecznego}

Miasta i miasteczka od zawsze były fizycznymi przejawami złożonej organizacji mającej na celu postęp w produkcji dóbr i świadczenia usług. Jako stały cel migracji w poszukiwaniu lepszej przyszłości ekonomicznej, miasta stały się obszarami opartymi na pracy i rozwijającymi się dzięki pracy. Typy architektury mieszkaniowej stosowane w tkance miejskiej, silnie odzwierciedlają czynności związane z typem pracy wykonywanej przez mieszkańców. Równowaga między mieszkaniem, pracą a zdrowiem w granicach miasta miała historycznie kluczowe znaczenie. XIV - wieczna epidemia dżumy przyczyniła się do rewolucyjnych przemian urbanistycznych w okresie renesansu. 
Starano się uporządkować przeludnione kwartały miejskie i ograniczyć w nich liczbę mieszkańców, rozwinąć infrastrukturę, wprowadzić szerokie ciągi komunikacyjne i duże otwarte place. Zgodnie z tymi zasadami projektowano idealne miasta renesansowe. Ponadto w XIX i XX wieku choroby zakaźne były jedną z przyczyn wprowadzania parków miejskich i terenów zielonych dla dzieci. Wraz z początkiem ery przemysłowej choroby wpłynęły na reformy sanitarne, przyczyniając się do rozwoju systemów wodnych i kanalizacyjnych. Ta podstawowa infrastruktura wymagała prostszych i szerszych ulic, co przyczyniło się do powstania współczesnego obrazu miasta, jaki znamy dzisiaj (Budds, D, 2020). Moderniści postrzegali projektowanie architektoniczne i urbanistykę jako środki leczące chorobę przeludnionych dzielnic, uwalniające je od epidemii gruźlicy, tyfusu i polio (Chang, V., 2020, Lubell, S., 2020).

Jeśli chodzi o kompozycję miejską, to należy przeanalizować zwykłe czynności mieszkańców. "Istnieje związek między działaniami jednostki związanymi z życiem miejskim a ryzykiem infekcji: patogeny rozprzestrzeniają się za pomocą ruchomych wektorów, plan i architektura miasta kształtują ich przepływy." (Lai K.Y., Webster C., Kumari S., Sarkar C, 2020) Odnosząc się do związku pomiędzy zdrowiem publicznym a warunkami życia, badania pokazują, że duże zagęszczenie prowadzi do rozprzestrzeniania się infekcji lotnych i przenoszonych drogą kropelkową (Capolongo, S., et al., 2020). Po wybuchu epidemii Covid19 pojawiły się prognozy kryzysu miast spowodowanego wysokim zagęszczeniem, z których wyłaniał się obraz opuszczonych centrów i zaniku tętniącego życia miejskiego - takiego jakie znamy. Autorzy nie podzielają tak radykalnych poglądów, ale przyłączają się do apeli o wprowadzenie koniecznych usprawnień. Planowanie przestrzenne powinno być brane pod uwagę przy omawianiu tematu wysokiej jakości przestrzeni do pracy w domu. W przedstawionych powyżej badaniach respondenci podkreślali znaczenie bezpośredniego światła słonecznego w mieszkaniu, możliwości kontaktu z zielenią dla jak najbardziej efektywnej pracy oraz warunków zapewniających wysoki standard życia. Taka sytuacja może być zapewniona tylko wtedy, gdy istnieją odpowiednie odległości między budynkami, pozwalające na przenikanie światła słonecznego do tkanki miejskiej. Aby umożliwić bliski kontakt z zielenią, konieczne są dobre decyzje urbanistyczne. Należy podkreślić, że dobry standard sąsiedztwa jest warunkiem wstępnym dla wysokiej jakości pomieszczeń mieszkalnych w wielopiętrowych budynkach mieszkalnych.

\subsubsection{Budynki mieszkalne o dużej gęstości i strategie przeciwdziałania zakażeniom}

We współczesnym mieście większość budynków mieszkalnych to budynki wielopiętrowe. Istnieje kilka sposobów, w jaki wielorodzinne budynki mieszkalne mogą być skonstruowane lub zmienione tak, aby były bezpieczne w przypadku pandemii Covid-19. Stosowanie dobrych praktyk konserwacyjnych, technologii ICT i rozwiązań bezdotykowych od wejścia do drzwi mieszkania poprawia higienę i bezpieczeństwo (Priday, C., 2020). Technologia może wspierać dystans społeczny, zapewniać użytkownikom bezdotykowy dostęp do mieszkań, który może być oparty na rozwiązaniach mobilnych, wykorzystujących głos lub na technologiach wykrywania gestów. Możliwa jest identyfikacja i uwierzytelnienie osób w celu przeprowadzenia kwarantanny, z wykorzystaniem czujników do biometrycznej weryfikacji głosu, tęczówki oka, rysów twarzy czy cech behawioralnych (Hossam N., Zaher E., 2020). Wnętrza pomieszczeń użyteczności publicznej w wielopiętrowych budynkach mieszkalnych mogą być dekorowane i wykańczane przy użyciu materiałów ograniczających wzrost lub rozprzestrzenianie się grzybów. Wraz z postępem nowoczesnych technologii, powierzchnie antybakteryjne z cząsteczkami srebra mogą być zintegrowane z meblami, tkaninami i dywanami w celu osiągnięcia właściwości higienicznych lub samoczyszczących. Technologia światła ultrafioletowego może zapewnić wymiernie bezpieczniejsze i czystsze środowisko i może być stosowana w windach lub na klatkach schodowych.

$Z$ architektonicznego punktu widzenia, rozwiązania zapobiegające zakażeniom mogą również obejmować szersze korytarze i drzwi. Niezbędne jest również zapewnienie odpowiedniej wentylacji zarówno w częściach wspólnych, jak i w mieszkaniach prywatnych. W budynkach wielopiętrowych standardowo powinny być instalowane systemy filtracji wody i powietrza. Należy podnieść poziom komfortu, zapewniając dostęp naturalnego światła słonecznego do powierzchni mieszkalnych oraz umożliwić mieszkańcom dostęp do zieleni - są to warunki zależne od szerszego kontekstu planowania miasta. Należy zachęcać do tworzenia ogrodów w pomieszczeniach (Makhno, S.,2020; Wainwright, O., 2020). 
Dyskusja na temat wielkości i planu mieszkania w kontekście bezpieczeństwa jest konieczna również ze względu na coraz powszechniejsze zjawisko współdzielenia mieszkań, szczególnie w metropoliach światowych. Rozmiary i układy mieszkań powinny umożliwiać zachowanie fizycznej odległości od siebie, zgodnie z krajowymi wytycznymi zdrowotnymi dotyczącymi mieszkań dzielonych. Należy pamiętać o fizycznym dystansie pomiędzy mieszkańcami, aby zapewnić komfort i bezpieczeństwo we wspólnych mieszkaniach. Brytyjski sondaż internetowy YouGov wykazał, że $31 \%$ dorosłych doświadczyło problemów ze zdrowiem psychicznym lub fizycznym z powodu jakości warunków życia w ich domach podczas blokady miast (Sansom, 2020). Co więcej, badanie wykazało, że 30000 Brytyjczyków spędziło czas zamknięcia miasta w jednopokojowych mieszkaniach (Peters T., Halleran A., 2020). W tym kontekście, unikanie małych, substandardowych mieszkań, stosowanie elastycznych rozwiązań mieszkaniowych, które mogą wspierać samoizolację w ramach wspólnych jednostek może stać się kluczowe w ograniczaniu rozprzestrzeniania się pandemii.

\subsection{Wyniki badań ankietowych}

Dane uzyskane z kwestionariuszy zostały skwantyfikowane, porównane i przeanalizowane. $78 \%$ respondentów zadeklarowało, że musiało przestawić się na pracę lub naukę online. Większość osób twierdzących, że nie przestawiła się na aktywność online, należała do grupy wiekowej powyżej 65 lat. Mimo że izolacja społeczna powodowała negatywne uczucia niepokoju lub irytacji, wydaje się, że doświadczenie to nie było całkowicie negatywne, ponieważ mniej niż połowa $(43 \%)$ respondentów wolałaby powrócić do pracy lub nauki wyłącznie w trybie stacjonarnym. Wynik ten wskazuje, że pandemia Covid-19 pobudziła trend, który prawdopodobnie się utrzyma. 57\% członków grupy chciałoby kontynuować pracę i naukę w sposób hybrydowy. Ponadto $17 \%$ zadeklarowało, że chciałoby pozostać całkowicie online. Może to oznaczać, że przeniesienie działalności do Internetu nie jest jedynie odpowiedzią na krótkotrwałą sytuację kryzysową.

Istnieją dowody na to, że otwartość na wirtualną pracę jest związana z warunkami, w jakich się pracuje. Respondenci, którzy postrzegają swoją obecną przestrzeń do pracy w domu jako wystarczającą w stosunku do swoich potrzeb, są bardziej otwarci na pracę online teraz i w przyszłości. W grupie, która udzieliła pozytywnej odpowiedzi na pytanie "Czy Twoje miejsce pracy jest wystarczające?", 68\% jej członków chciałoby kontynuować pracę lub naukę częściowo z domu po zakończeniu sytuacji kryzysowej. W grupie, w której warunki pracy są niewystarczające, odsetek ten wynosi tylko $54 \%$.

Wyniki odpowiedzi na pytanie: czy po zakończeniu sytuacji kryzysowej chciałbyś/chciałabyś nadal pracować lub częściowo uczyć się w domu, zostały pokazane na ilustracji nr 1.

Zmiany przestrzenne w projektowaniu mieszkań są warte rozważenia, gdyż kształtują decyzje ludzi o sposobie wykonywania pracy. Warunki życia, które są odpowiednie, gdy pracuje się wyłącznie poza domem, stają się gorsze, gdy praca zaczyna być wykonywana w miejscu zamieszkania. Sytuacja ta rodzi pytania dotyczące wprowadzenia wytycznych budowlanych zalecających uwzględnienie miejsca pracy. Tendencję do wybierania większych mieszkań lub domów rodzinnych uwidaczniają już dane z rynków nieruchomości, od początku pandemii. Dodatkowa przestrzeń stała się bardziej pożądana. Upowszechnienie przekonania, że dobrze zaprojektowane domowe biuro lub przynajmniej zamknięta przestrzeń do pracy jest niezbędna, będzie zapewne wymagało czasu. Co ciekawe, indywidualna ocena samodzielnie zorganizowanej przestrzeni do pracy jest wysoka. Na pytanie o wystarczalność przestrzeni do pracy $74 \%$ deklaruje, że przestrzeń jest wystarczająca, mimo że tylko $13 \%$ posiada osobny pokój do pracy. (Fig. 2)

Obserwacja ta pokazuje, że społeczeństwo nie dostrzega jeszcze potrzeby zapewnienia miejsca pracy o wysokim standardzie. Domowe "kąciki do pracy", oprócz tego, że są mało komfortowe, mogą stanowić zagrożenie dla zdrowia użytkownika. Z drugiej strony, praca wykonywana z sypialni czy salonu może być wydajna i nie musi stanowić zagrożenia dla zdrowia, pod warunkiem, że organizacja pracy, wyposażenie i oświetlenie będą zgodne z zasadami ergonomii - tak jak profesjonalnie zaaranżowane przestrzenie biurowe w biurowcach. 
Respondenci zapytani o miejsce pracy w domu, najczęściej wskazywali: sypialnię - 44\%, salon $33 \%$, kuchnię - $5 \%$ oraz przestrzenie zewnętrzne, takie jak ogród, balkon czy garaż - $5 \%$ (Fig. 3). Wyniki te wskazują, że wprowadzenie i upowszechnienie zbioru wytycznych dotyczących urządzania wysokiej jakości przestrzeni do pracy byłoby niezbędne.

Niektórzy z respondentów dołączyli do swoich ankiet zdjęcia ilustrujące zaaranżowane $\mathrm{w}$ domu miejsca pracy. Przykłady załączonych zdjęć pokazane są poniżej i mogą być traktowane jako dodatkowy wgląd w przypadkowo zaaranżowane sytuacje. Poza przykładami $A$, B, które ukazują wydzielone pracownie, C (sypialnia) i D (ogród) przedstawiają przypadkową przebudowę i adaptację do celów zawodowych. Problem ergonomii w miejscu pracy zaaranżowanym w domu jest istotny ze względu na bardzo długi czas, jaki respondenci deklarują w nim spędzać. $44 \%$ spośród nich twierdzi, że pracuje w domu ponad 8 godzin dziennie, a kolejne $26 \%$ od 5 do 8 godzin. W związku z tym zdrowe środowisko pracy nabiera kluczowego znaczenia. Prawidłowa wysokość krzesła, odpowiednie rozmieszczenie urządzeń, światło i właściwa postawa przy biurku - mogą pomóc w utrzymaniu zdrowej rutyny. Profesjonalnie zaprojektowane i wyposażone biura muszą spełniać te standardy. Niekoniecznie dotyczy to biur przygotowanych do pracy w domu. (Fig. 4)

Respondenci pytani o zmiany, jakie wprowadziliby w domowym miejscu pracy, twierdzili, że powiększyliby lub zmienili aranżację przestrzeni do pracy lub nauki w domu. Jako istotne czynniki komfortu wskazywali lepszy dostęp do naturalnego światła, odseparowanie od hałasu oraz większą prywatność. Warto podkreślić, że kwestie takie jak zwiększenie dopływu światła słonecznego czy ilości zieleni przed oknami są związane z decyzjami urbanistycznymi, dlatego też autorzy uwzględnili je w badaniach bibliograficznych.

\section{ZESTAW WYTYCZNYCH DLA MIEJSC PRACY LUB NAUKI ZLOKALIZOWANYCH W MIESZKANIACH}

W oparciu o wyniki analizy ankietowej i badań bibliograficznych, przy aranżacji lub przebudowie pomieszczeń do pracy lub nauki, należy uwzględnić następujące wytyczne:

- Jeśli to możliwe, należy zagospodarować miejsca pracy/studiów jako oddzielne pomieszczenia, które zapewnią użytkownikom najlepszą izolację i prywatność. W przypadku adaptacj pomieszczeń na pomieszczenia do pracy/studiów należy uwzględnić izolację akustyczną ścian. Jeżeli nie jest to możliwe, należy zastosować miejsca zapewniające prywatność podczas godzin pracy. Miejsca do pracy lub nauki mogą być urządzone w sypialniach, pokojach dziennych i wielu innych pomieszczeniach pod warunkiem prawidłowej organizacji.

- Pierwszeństwo mają miejsca z naturalnym światłem - należy lokalizować miejsca pracy w pobliżu okien i zapewnić odpowiednie intensywne sztuczne oświetlenie miejsc pracy. Dodatkowe źródła światła są niezbędne do prowadzenia wideokonferencji lub rejestracji materiałów wideo. W tym celu konieczne jest zastosowanie skutecznego systemu zaciemniającego (zasłony, rolety).

- W domowym biurze należy zorganizować strefy zadań z odpowiednią hierarchią: główna strefa robocza ze stanowiskiem komputerowym, w razie potrzeby kreatywne blaty do rysowania $i$ pisania, strefa do czytania i relaksu, najlepiej połączona z biblioteką, zewnętrzna przestrzeń robocza, na przykład na tarasie, aby uniknąć monotonii.

- Należy używać elastycznych mebli z dużą ilością miejsca do przechowywania, z odpowiednimi separatorami. Wszystkie meble i stanowiska komputerowe muszą spełniać standardy ergonomiczne oraz wykorzystywać materiały i wykończenia łatwe do czyszczenia i odkażania. Ponadto biuro wymaga odpowiedniego wyposażenia technicznego.

- Należy wziąć pod uwagę możliwe konfiguracje i tła dla wideokonferencji. Często możliwe jest posiadanie więcej niż jednego układu wideokonferencyjnego.

- Aby zredukować stres i zachować doskonałą równowagę między pracą a życiem prywatnym, wprowadź w mieszkaniu miejsca do innych aktywności. Mogą to być np. miejsca do ćwiczeń, relaksu, rozrywki i inne. 


\section{MODELOWE STUDIUM PRZYPADKU - APARTAMENT W GENUI, WŁOCHY}

W sierpniu 2021 roku w Genui we Włoszech zrealizowano projekt apartamentu, w którym zastosowano wytyczne wynikające z opisanych powyżej badań. Pełni on rolę studium przypadku (research by design), służącego do obserwacji i oceny zastosowanych rozwiązań. Dawny pokój dziecięcy został przekształcony w przestrzeń biurową przeznaczoną dla dwóch użytkowników. Wnętrze pomieszczenia zostało podzielone na główną strefę roboczą z dwoma biurkami, kącik czytelniczy z miękkimi meblami i biblioteką oraz dodatkową, tymczasową przestrzeń roboczą na balkonie. Wprowadzono ruchome, elastyczne blaty robocze, które umożliwiają kreatywną pracę z możliwością filmowania lub transmisji wideo. Biuro zostało zaprojektowane w taki sposób, aby dobrze sprawdzało się w następujących trybach pracy:

- Wideokonferencje

- Wideokonferencje z pracownią rysunku i malarstwa

- Cicha praca lub nauka (z wykorzystaniem zasobów domowej biblioteki)

- Praca twórcza (rysowanie, malowanie) i filmowanie procesu

- Czytanie i relaks.

\subsection{Ergonomia}

W celu zapewnienia optymalnego przebiegu wideokonferencji zastosowano dodatkowe sztuczne oświetlenie oraz wsporniki do kamer internetowych, które umożliwiają ich prawidłowe ustawienie. Wprowadzono skuteczny system zaciemnienia za pomocą rolet. Na ścianach pokoju zastosowano panele izolacji akustycznej, aby odizolować go od reszty mieszkania. Dla zapewnienia cichej pracy lub nauki, biurka zostały usytuowane blisko okien. W celu spełnienia wymogów ergonomii zastosowano pełną regulację: wysokość biurek i krzeseł biurowych można łatwo regulować tak, aby stopy spoczywały płasko na podłodze lub na podnóżku, a uda były równoległe do podłogi. Krzesła wspierają krzywizny kręgosłupa. Regulacja podłokietników umożliwia podparcie ramion i rozluźnienie barków. Pomieszczenie zostało wyposażone w podnóżek w przypadku korzystania z nieruchomych blatów roboczych. Aby pomieścić materiały do pracy wprowadzono elastyczne meble magazynowe. Do pracy twórczej (rysowanie, malowanie) i filmowania przewidziano dodatkowe ruchome blaty robocze z dodatkowym oświetleniem. Wszystkie często używane przedmioty (telefon, zszywacz, czy materiały drukowane) zostały umieszczone blisko, aby wygodnie było do nich sięgać. Monitor został umieszczony bezpośrednio przed miejscem siedzącym, góra ekranu nieco poniżej poziomu oczu. Po lewej stronie, jedno okno wychodzi na zewnątrz - na zieleń, co umożliwia uwolnienie od stresu związanego z ekspozycją na monitor. Monitor jest umieszczony bezpośrednio za klawiaturą, a mysz komputerowa pozostaje w zasięgu ręki na tej samej powierzchni. Strefa wydzielona do nauki i relaksującej lektury została wyposażona w miękkie meble i biblioteczkę. Obszar ten umożliwia zmianę pozycji ciała podczas pracy, gdy czynności zawodowe związane są z przyswajaniem informacji, np. czytanie materiałów drukowanych, ale nie wymagają korzystania z komputera.

\subsection{Stylistyka inspirowana zielenią i wzorami roślinnymi}

Koncepcja "wyposażenia w rośliny" została wprowadzona jako podstawowy atrybut estetyki w pracowni. Zieleń stała się główną ozdobą pomieszczenia, a wszystkie inne elementy wystroju powtarzają jej wzory, kolory i nastroje. Pracownia została pomalowana na kolor zieleni szałwii, która optycznie poszerza pomieszczenie w kierunku balkonu i intensywnej, naturalnej zieleni na zewnątrz. $\mathrm{Na}$ balkonie przewidziano również dodatkową, niewielką przestrzeń do pracy. Motywy liści roślinnych są obecne na miękkich meblach przestrzeni czytelniczej, co wprowadza ducha spokoju i podkreśla związek z naturą. Meble wykazują współczesną stylistykę, a ściany ozdobiono czarnobiałymi fotografiami, aby uzyskać półformalny wygląd środowiska pracy, jako tło do wideokonferencji. Stworzenie formalnego wyglądu przestrzeni jest istotnym elementem nowej kultury pracy związanej z ujawnianiem widoków przestrzeni prywatnych podczas wideokonferencji. 


\subsection{Odreagowanie stresu}

Alternatywna przestrzeń do pracy została zaaranżowana na wschodnim balkonie. Istnieje możliwość zamknięcia go roletą. Studio posiada również bezpośredni dostęp do strefy fitness, która została zaaranżowana w miejscu wyburzonego pomieszczenia magazynowego, znajdującego się wcześniej w centralnym punkcie mieszkania. W skład strefy sportowej wchodzi jeden element stały: rower treningowy oraz kilka wyjmowanych mat do ćwiczeń, maty do jogi, mata do masażu relaksacyjnego, a także ciężarki do ćwiczeń.

\section{DYSKUSJA}

Popularyzacja pracy w domu stała się faktem i ponaglającym wyzwaniem dla architektów i projektantów wnętrz. Obawy związane z założoną przez autorów hipotezą pracy potwierdziły się. Znaczna część respondentów deklarowała, że ich prywatne mieszkania są niewystarczające do nauki lub pracy zdalnej. Jednocześnie udowodniono wyraźną zależność między warunkami pracy w domu a akceptacją koncepcji smart working: im gorsze warunki pracy w prywatnym mieszkaniu, tym mniejsza akceptacja podejścia do WFH. Należy podkreślić, że zachowania indywidualne dotyczące czasu spędzanego w pracy oraz czasu poświęconego innym aktywnościom, takim jak trening czy relaks, mają decydujący wpływ na poprawę równowagi między życiem zawodowym a prywatnym w trakcie i po przymusowej izolacji społecznej.

Podsumowując, wyniki uzyskane w badaniu kwestionariuszowym i badaniu metodą projektu są zgodne $z$ wnioskami spotykanymi w publikacjach. W tym momencie pandemii autorzy nie zgadzają się z definitywnymi i negatywnymi stwierdzeniami dotyczącymi przyszłości miast i poglądami, że jedyną adekwatną odpowiedzią na pandemię jest jednorodzinny dom wolnostojący. Takie podejście byłoby szkodliwe i potencjalnie katastrofalne dla urbanistyki. Autorzy ustalili środki i działania, które pomogą uczynić domowe biura zlokalizowane w wielorodzinnych kondominiach wygodnymi, wydajnymi i stymulującymi. Plany mieszkań oferują przestrzenie dla różnych funkcji: sportu, treningu, relaksu; wspólne działania mają na celu zapewnienie różnorodnych aktywności i zachowanie równowagi między życiem zawodowym a prywatnym. W tym kontekście warto zastanowić się, że w historycznych wzorcach życia i pracy, wykonywanie czynności zawodowych w domu było normą. Tradycyjne warsztaty rzemieślników, kupców i właścicieli sklepów znajdowały się zazwyczaj na parterze kamienic, a ich właściciele mieszkali na wyższych piętrach. Życie prywatne i zawodowe było ze sobą powiązane, a co ważniejsze, osadzone w szerszej, społecznej tkance kwartału miasta. W dzisiejszych czasach normą społeczną stało się ścisłe oddzielenie tego, co prywatne, od tego, co zawodowe. A ponieważ praca, wykonywana w odległym, anonimowym biurze, stała się siłą dominującą, inne aspekty straciły na znaczeniu. Elastyczny model pracy sprawił, że dom stał się bardziej zamieszkany. Czy może to wpłynąć również na życie społeczne poza czterema ścianami prywatnych mieszkań? Być może mogłoby to odbudować tradycyjne zaangażowanie społeczne na poziomie sąsiedzkim i pomóc w celebrowaniu danego miejsca.

Inna opinia, często spotykana w badaniach bibliograficznych, zwiastuje koniec trendu na otwarte przestrzenie $w$ architekturze mieszkaniowej, spowodowanego koniecznością dzielenia pokoi przez członków rodziny lub współlokatorów w celu spokojnej pracy i nauki. Te argumenty mogą być istotne w przypadku małych jednostek mieszkalnych. Rzeczywiście, w małym mieszkaniu priorytetem byłoby zapewnienie prywatności i separacji wszystkim członkom rodziny. Jednak rozwiązania przedstawione w części poświęconej badaniom projektowym (3.3.) pokazują, że możliwe jest zainstalowanie dobrze zorganizowanych, oddzielnych, wysuwanych jednostek biurowych w istniejących sypialniach, pokojach dziennych i innych pomieszczeniach. W wielu przypadkach pozwoliłoby to na zachowanie percepcji rozległej, niczym nie ograniczonej przestrzeni. W dużych mieszkaniach, gdzie są wolne pokoje, które można zamknąć, centralna otwarta przestrzeń mogłaby nadal być atrakcyjnym miejscem spotkań, zajęć rodzinnych, wypoczynku, rozrywki, wykorzystywanym do ćwiczeń i innych zajęć. Mogłoby to oznaczać koniec klaustrofobicznych, opresyjnych, zamkniętych środowisk.

Planowane badania w tym obszarze tematycznym, które autorzy już podjęli, obejmują analizy zajęć i rutynowych czynności wykonywanych w domu w okresie blokady: rozrywki, ćwiczeń, a także go- 
towania i nawyków żywieniowych. Ponadto, istotne stanie się zrozumienie zaangażowania czasowego oraz wpływów pomiędzy różnymi działaniami i przestrzeniami.

\section{WNIOSKI}

Koniec pandemii COVID-19 wciąż wydaje się odległy. Jednak akceptacja dla smart workingu będzie najprawdopodobniej rosła, a cyfrowa rewolucja kulturowa będzie trwała nawet po zakończeniu epidemii. Po zakończeniu badań okazało się, że wiedza ekspercka na temat aranżacji miejsc pracy w domu powinna być szeroko rozpowszechniana. Zasady ergonomii w tworzeniu zdrowych, wygodnych biur są bardzo rygorystycznie przestrzegane w przypadku projektowania profesjonalnych aranżacji biurowych. Nadszedł czas, aby podobny standard ustanowić dla biur domowych. Społeczeństwo nie powinno być pozostawione samemu sobie $w$ próbach poradzenia sobie $z$ tym zadaniem. Nieprofesjonalne, nieodpowiednie aranżacje spowodują zagrożenia dla zdrowia i spadek akceptacji dla pracy zdalnej, jako mniej wydajnej i mniej komfortowej. Firmy pozwalające pracownikom na pracę $\mathrm{w}$ domu powinny zapewnić im pomoc, know-how, a nawet wstępnie zaprojektowane meblościanki, aby wesprzeć ich w radzeniu sobie $z$ tymi trudnym zadaniami.

\section{BIBLIOGRAPHY}

Alter, L. (2020). Architecture after the coronavirus. available at: https://www.treehugger.com/greenarchitecture/architecture-after-coronavirus.html (Accessed 15 April 2020)

Belzunegui-Eraso, A., Erro-Garcés, A. (2020). Teleworking in the context of the Covid-19 crisis. Sustainability, 12(9), 3662. https://doi.org/10.3390/su12093662. (Accessed 22 April 2020)

Budds, D. (2020). Design in the age of pandemic https://www.curbed.com/2020/3/17/21178962/designpandemics-coronavirus-quarantine (Accessed 27 March 2020)

Chang, V. (2020). The post-pandemic style. available at: https://slate.com/business/2020/04/coronavirusarchitecture-1918-flu-cholera-modernism.html (Accessed 28 April2020)

Capolongo, S., Rebecchi, A., Buffoli, M., Letizia, A., \& Carlo, S. (2020). COVID-19 and cities: From urban health strategies to the pandemic challenges. A decalogue of public health opportunities. Acta Biomedica, 91(2), 13-22. https://doi.org/10.23750/abm. v91i2.9515. (Accessed 15 April 2020)

Hossam N., Zaher E., Design Solutions For Interior Architecture Post Coronavirus (COVID-19) Décor Department, Faculty of Fine Arts, Mansoura University, Egypt JAARS - Volume 1 - Issue 2 - December 2020

Howis, COID-19 Experience Transforming Sustainability Requirements of Residential Buildings? A ReviewGalymTokazhanov1 (Accessed 28 April 2020)

Ka Yan Lai, Webster C., Kumari S., Sarkar C., The nature of cities and the Covid-19 pandemic Current Opinion in Environmental Sustainability 2020, 46:27-31, www.sciencedirect.com

Lubell, S. (2020). Commentary: Past pandemics changed the design of cities. Six ways covid-19 could do the same. Available at: https://www.latimes.com/entertainment-arts/story/2020-04-22/coronavirus-pandemicsarchitecture-urban-design (Accessed 27 April 2020)

Lai K.Y., Webster C., Kumari S., Sarkar C., The nature of cities and the Covid-19 pandemic, Elsevier: Current Opinion in Environmental Sustainability, October $2020 \mathrm{https://doi.org/10.1016/j.cosust.2020.08.008}$

Makhno, S. (2020). Life after coronavirus: How will the pandemic affect our homes? Dezeen. available at: https://www.dezeen.com/2020/03/25/life-after-coronavirus-impact- homes-design-architecture/ (Accessed 1 April 2020) 
Marr, B. (2020). How the COVID-19 pandemic is fast-tracking digital transformation in companies. https://www.forbes.com/sites/bernardmarr/2020/03/17/ (Accessed 15 April 2020).

Nakada I., Urban R., COVID-19 pandemic: Impacts on the air quality during the partial lockdown in São Paulo state, Brazil, The Science of the Total Environment, 730 (2020), p. 139087

Naglaa A. Megaheda, Ehab M. Ghoneim Antivirus-built environment: Lessons learned from Covid-19 pandemic, Sustainable Cities and Society ELSEVIER Volume 61, October 2020, 102350 (Accessed 15 April 2020)

Peters T., Halleran A., How our homes impact our health: using a COVID-19 informed approach to examine urban apartment housing Archnet-IJAR Volume 15 Issue 1,25 December 2020, ISSN: 2631-6862

Priday, C. (2020). Architecture after coronavirus. https://exepose.com/2020/_(Accessed 29 April 2020).

Rassia S., How Architecture Fails in Conditions of Crisis: a Discussion on the Value of Interior Design over the COVID-19 Outbreak, Springer SN Operations Research Forum, Article number: 13 2020, volume 1

Wainwright, O. (2020). Smart lifts, lonely workers, no towers or tourists: Architecture after coronavirus. Available at: https://www.theguardian.com/artanddesign/2020/apr/13/smart-lifts-lonely-workers-no-towersarchitecture-after-covid-19-cor- coronavirus (Accessed 18 April 2020)

Xiao Y., Becerik-Gerber B., Lucas G., Shawn C, Impacts of Working From Home During COVID-19 Pandemic on Physical and Mental Wellbeing of Office Workstation Users, J Occup Environ Med. 2021 Mar; 63(3): 181-190. 202023 November. doi: 10.1097/JOM.0000000000002097

\section{AUTHOR'S NOTE}

Agata Bonenberg - Full Professor and a Head of the Institute of Interior and Industry Design, at the Faculty of Architecture, Poznan University of Technology. Since 2014 has collaborated with Dipartimento di Architettura e Studi Urbani at Politecnico di Milano. She is a visiting professor at Chongqing Jiaotong University in China. In her professional career she worked for architectural practices throughout Germany, Australia, Scotland and Italy, including renowned Renzo Piano Building Workshop. In her research she deals with the subject of spaces that support, stimulate creativity and creative thinking. An expert in the field of universal and inclusive design. Author of utility models and patents.

Marco Lucchini - Architect, is Associate Professor at the School of Architecture Urban Planning and Building Construction and at the Department of Architecture and Urban Studies, Politecnico di Milano. He is visiting professor at Faculty of Architecture of Poznan University of Technology. His research lines concerns the topic of housing design at different scales, the relationship among tectonics, building construction and expression, the narrativity in architectural design and the identity of architecture in Barcelona and Milano modernist architecture. 


\section{O AUTORACH}

Agata Bonenberg - Profesor zwyczajny i kierownik Instytutu Architektury Wnętrz i Wzornictwa Przemysłowego, na Wydziale Architektury Politechniki Poznańskiej. Od 2014 roku współpracuje z Dipartimento di Architettura e Studi Urbani na Politecnico di Milano. Jest profesorem wizytującym na Chongqing Jiaotong University w Chinach. W swojej karierze zawodowej pracowała dla biur architektonicznych w Niemczech, Australii, Szkocji i we Włoszech, w tym dla renomowanej pracowni Renzo Piano Building Workshop. W pracach badawczych zajmuje się tematyką przestrzeni wspierających, stymulujących kreatywność i twórcze myślenie. Ekspert w zakresie projektowania uniwersalnego i inkluzywnego. Autorka wzorów użytkowych i patentów.

Marco Lucchini - Architekt, profesor nadzwyczajny w Scuola di Architettura Urbanistica Ingegneria delle Costruzioni, Politecnico di Milano. Visiting professor na Wydziale Architektury Politechniki Poznańskiej. Jego prace badawcze dotyczą projektowania domów w różnych skalach, relacji między tektoniką, konstrukcją i ekspresją budynku, narracyjność w projektowaniu architektonicznym oraz tożsamości architektury w barcelońskiej i mediolańskiej architekturze modernistycznej.

Contact | Kontakt: agata.bonenberg@put.poznan.pl; marco.lucchini@polimi.it 